\title{
Power Census of the United States*
}

\author{
Ninety Per Cent of the Total Power Produced by the Consumers Themselves
}

By Davis H. 'Tuck

IN 1909 , it is reported in the thirteenth United States census, 18,760,686 primary horse-power was generated or rented by manufacturing establishments in the United States. Table 2 shows the distribution.

Ninety per cent of the horse-power in 1909 was that of engines or motors owned by the manufacturing establishments themselves, and 10 per cent was rented power, mostly electric. Especially striking is the increased use facturing industries in 1909. The relative total amount used is largely dependent upon the character of the industries predominant in each division or state, and the extent to which the different kinds are used depends upon the character of the industries and the situation of each State as to supplies of coal, petroleum and gas and the availability of water power

In every State except Maine and Vermont, steam

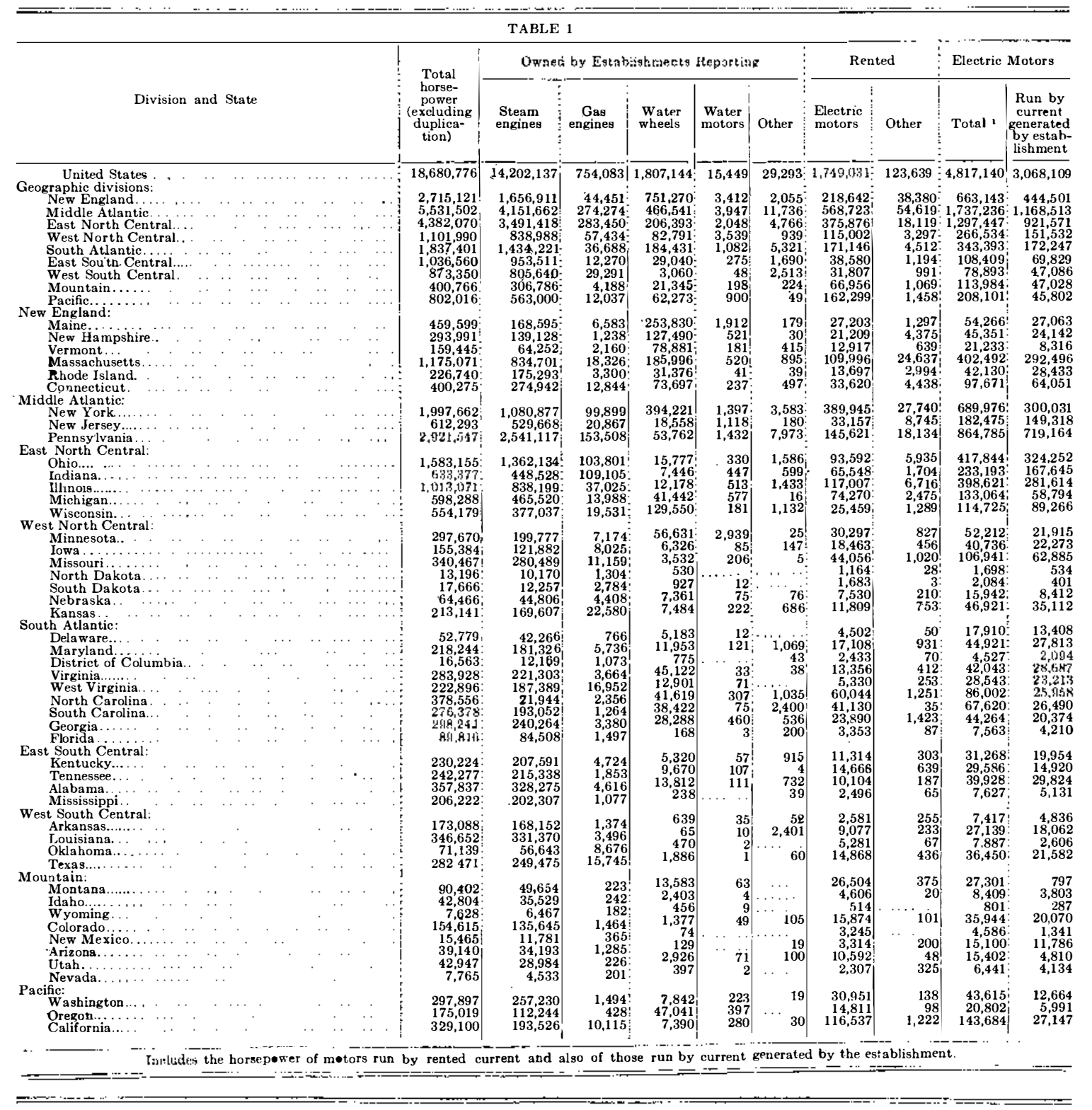

\begin{tabular}{|c|c|c|c|c|c|c|c|c|c|}
\hline \multicolumn{9}{|c|}{ TABLE 2} & \\
\hline \multirow{2}{*}{ Power } & \multicolumn{3}{|c|}{ Number of Engines or Motors } & \multicolumn{3}{|c|}{ Horsepower } & \multicolumn{3}{|c|}{$\begin{array}{l}\text { Per Cent. Distribution } \\
\text { of Horsepower }\end{array}$} \\
\hline & 1909 & 1904 & 1899 & 1909 & 1904 & 1899 & 1909 & 1904 & 1899 \\
\hline Primary power, total. & 408,472 & 231,363 & 168,143 & $18,680,776$ & $13,487,707$ & $10,097,893$ & 100.0 & 100.0 & 100.0 \\
\hline 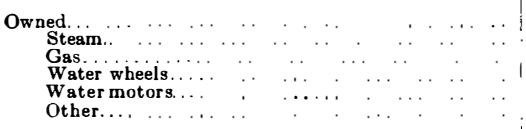 & $\begin{array}{r}209,163 \\
153,482 \\
34,352 \\
20,126 \\
1,203 \\
\ldots . . .\end{array}$ & $\begin{array}{r}169,774 \\
127,267 \\
21,515 \\
19,595 \\
1,397\end{array}$ & 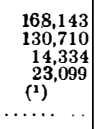 & $\begin{array}{r}16,808,106 \\
14,202,137 \\
75,8083 \\
1,80,7144 \\
15,494 \\
29,293 \\
29\end{array}$ & $\begin{array}{r}12,854,805 \\
10,285,348 \\
289,423 \\
1,641,949 \\
52,931 \\
92,154\end{array}$ & 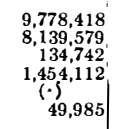 & $\begin{array}{r}90.0 \\
76.0 \\
4.0 \\
9.7 \\
0.1 \\
0.2\end{array}$ & $\begin{array}{c}95.3 \\
80.3 \\
2.1 \\
12.2 \\
(2) \\
0.7 \\
0.7\end{array}$ & $\begin{array}{l}96.8 \\
80.6 \\
1.3 \\
14.4 \\
(1)\end{array}$ \\
\hline 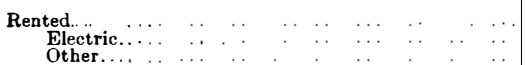 & $\begin{array}{r}199,309 \\
199,309 \\
\ldots \ldots\end{array}$ & $\begin{array}{l}61,589 \\
61,589\end{array}$ & (2) & $\begin{array}{r}1,872,670 \\
1,749,931 \\
123,639\end{array}$ & $\begin{array}{l}632,902 \\
441,589 \\
191,313:\end{array}$ & $\begin{array}{l}319,475 ! \\
182,562 ! \\
136,913 !\end{array}$ & $\begin{array}{r}10.0 \\
9.4 \\
0.7\end{array}$ & $\begin{array}{c}4.7^{3} \\
3.3 \\
1.4\end{array}$ & $\begin{array}{l}3.2 \\
1.8 \\
1.4\end{array}$ \\
\hline $\begin{array}{l}\text { Electric motors. } \\
\text { Run by current generated by establishment } \\
\text { Run by rented power... }\end{array}$ & $\begin{array}{l}388,854 \\
189,545 \\
199,309\end{array}$ & $\begin{array}{c}73,119 \\
73,119 \\
(31)\end{array}$ & 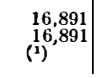 & $\begin{array}{l}4,817,140 \\
3,068,109 \\
1,749,031\end{array}$ & $\begin{array}{r}1,592,475 \\
1,150,886 \\
441,589\end{array}$ & $\begin{array}{l}492,936: \\
310,374 \\
182,562\end{array}$ & $\begin{array}{r}100.0 \\
63.7 \\
36.3\end{array}$ & $\begin{array}{r}100.0 \\
72.3 \\
27.7\end{array}$ & $\begin{array}{r}100.0 \\
63.0 \\
37.0\end{array}$ \\
\hline
\end{tabular}

of gas engines and of electric power, both that rented from outside concerns and that generated by the manufacturers. The total horse-power of electric motors in 1899, including those operated by purchased current and by current generated in the establishment, wa 492,936 ; in 1909 it was $4,817,140$, nearly ten times a great.

Renting electric power is rapidly becoming mor common among small establishments, while there is tendency for the large concerns to use electric motor for applying power which they themselves generate.

The largest amount of electric power is used by the steel works and rolling mills, the next largest being the foundries and machine shops. In the former the electric power is a little over one third of the total amount of primary power and in the latter nearly three fourths. Table 1 shows, in geographic divisions, the amount of each of the several kinds of power used in manu* Reproduce from power. engines are the most important source of power. The proportion which gas-engine power represents of the total is larger in the East North Central division than in any other division, partly on account of the proximity of gas wells. The Middle Atlantic States rank next in the proportion of the total developed by gas engines. For power obtained by waterwheels owned by the manufacturing establishments, New England ranks far ahead of the other divisions both in the absolute amount of power and in the proportion which water power represents of the total. More than two fifth derived from waterwheels owned by manufacturing establishments is found in New England, and more than one fourth of the power of the New England factorie is derived from waterwheels. The Middle Atlantic division ranks next.

The largest absolute amounts of power of electric motors (including both those operated by current generated in the establishment and those operated by purchased current) are reported from the Middle Atlanic, the East North Central and New England divisions. The leading individual States using gas engines to develop power are Pennsylvania, Indiana, Ohio, New York, Illinois, Kansas and New Jersey. In the use of waterwheels to develop power the States are New York, Massachusetts, Wisconsin, New Hampshire, Vermont, Connecticut, Minnesota, Pennsylvania, Oregon, Virginia, North Carolina and Michigan.

In the absolute amount of electric power for manufacturing, Pennsylvania leads, followed by New York, Ohio, Massachusetts, Illinois, Indiana and New Jersey.

\section{Green Vegetables and Their Uses in the Diet}

IT used to be said that a French housewife could feed her family upon what an American family would throw into their garbage barrel. This is probably no longer true. Though the abundance of food-products in the United States, and inveterate tradition, may still have the effect of keeping Americans somewhat behind the older populations in this matter of domestic economy, it is impossible to doubt that the influx of Germans, Italians and other new elements of population from Continental Europe has taught us the use as food of many vegetables and parts of vegetables which had formerly seemed useless.

In a bulletin on "Green Vegetables and their Uses in the Dist," Mr. C. F. Langworthy, Chief of Nutrition Investigations in the Department of Agriculture, has done much to spread information which ought to be helpful at this time, when the cost of living is a subject of incessant complaint. Even if much of the matter set forth in this bulletin is already familiar to the well-informed housewife, there are many who are by no means well-informed; and authoritative statements emanating from a Government bureau, and based upon careful experiments, should have some practical effect upon the dietary usage of the millions.

Mr. Langworthy's summing up is a plea for the increased use of succulent vegetables in American diets. This increased use, he predicts, will come with improved methods of production and transportation. It is not claimed, of course, that green vegetables add much to the nutrient and fuel values of food; but quite as important as these actual values is the hygenic effect which these vegetables produce in three ways: the supply of necessary mineral matter; added bulk, which is necessary for the proper digestion of the more concentrated food materials; and variety, which is so necessary for the maintenance of healthy appetite. "The great number of fancy foods, pies, cakes, and so on, which American housewives so often consider necessary, are often referred to as showing their ingenuity in providing variety from a few staple materials. They can get much greater variety without anything like as much labor by utilizing such fruits and vegetables as those discussed in this article.

To go back to the beginning of the bulletin, we are told that okra, a native African vegetable, has been cultivated for now more than a thousand years, and that rhubarb was introduced into Europe as early as the tenth century. On the other hand potatoes-as everyone knows - and Indian corn are the agricultural gifts to civilization of the aboriginal Red Man. Tomatoes are one of the newest foodstuffs in existence, having been, in their undeveloped form, regarded as merely ornamental until within the last two generations. It is comforting to see the bugaboo of cancer, as a result of eating tomatoes, disposed of as "without foundation" on the authority of this Government bulletin.

Among the most recent additions to the list of edible reen vegetables given here are New Zealand spinach, udo and dasheen. The introduction of new varieties is part of the work of the Department of Agriculture, but there appears to be no provision for teaching American cooks how to use as additions to ordinary diet such easily obtainable things as the leaves of the grape vine. These obtainable things as the leaves of the grape vine. These
leaves are used in Turkey in the preparation oi several dishes, one being a sort of forcement balls which are a characteristic of wedding banquets. Another exotic addition here suggested is the nasturtium flower, though nothing is said of the use of the nasturtium seed vessel, which makes an excellent pickle in some countries. From the Chinese we may hope some day to learn the merits of bamboo shoots as food, canned bamboo shoots being already "not uncommon in American cities and towns where Chinese foods are on sale."

Of all families of human-food plants the crucifers are perhaps the most largely represented-cabbage, kale, carliflower, mustard belong in this group. The family 